American Journal of Animal and Veterinary Sciences 5 (3): 221-227, 2010

ISSN $1557-4555$

(C) 2010 Science Publications

\title{
Effects of Enzyme Supplementation on Performance, Carcass characteristics, Carcass Composition and Some Blood Parameters of Broiler Chicken
}

\author{
H. Hajati \\ Department of Animal Science, College of Animal Science and Fisheries, \\ Sari Agricultural Sciences and Natural Resources University, P.O. Box 578, Sari, Iran
}

\begin{abstract}
Problem statement: Endogenous enzymes of broilers cannot adequately digest nonstarch polysaccharides and subsequently the ingestion of high levels of soluble NSP leads to increased digesta viscosity and reduced nutrient digestibility and absorption. Supplementation of NSPs degrading enzymes may remove the anti nutritive effects of NSPs and release some nutrients (starch, protein) from these elements. Therefore, in a completely randomized design the effects of a multi-enzyme (Endofeed $\mathrm{W}$ produced from Aspergillus niger, with minimum activity of $2250 \mathrm{u} \mathrm{g} \mathrm{g}^{-1}$ xylanase and $700 \mathrm{u} \mathrm{g} \mathrm{g}^{-1} \beta$-glucanase) supplementation on performance, carcass characteristics, carcass composition and some blood parameters in Cobb 500 broilers fed on corn-soybean meal-wheat diets were studied. Approach: A total of 150 one-day-old broiler chicks (Cobb 500) were used in a completely randomized design with 2 treatments and 3 replicates. The main ingeridients of diets included corn, soybean meal and wheat. The enzyme levels added to the diets were 0.00 (control) and $500 \mathrm{mg} \mathrm{kg}{ }^{-1}$ DM. Results: Enzyme supplementation significantly improved relative growth, energy efficiency and protein efficiency from 11-28 days of age. Adding enzyme significantly decreased body weight gain, feed intake and improved feed to gain ratio, energy efficiency and protein efficiency from 29-44 days of age $(\mathrm{p}<0.05)$. Relative growth, energy efficiency and protein efficiency was increased and body weight gain, feed intake and feed to gain ratio was decreased by enzyme supplementation from 1-44 days $(p<0.05)$. Enzyme addition significantly increased carcass and thighs + drumsticks percentages at 44 days of age. Adding enzyme significantly increased the concentration of blood Triiodothyronine $\left(\mathrm{T}_{3}\right)$ at 28 and 44 days and reduced the concentration of blood Thyroxine $\left(\mathrm{T}_{4}\right)$ at 44 days of age. Enzyme inclusion increased the concentration of blood total cholesterol at 10, 28 and 44 days of age, however triglyceride concentrations increased at 10 and 44 days $(\mathrm{p}<0.05)$. The concentration of blood uric acid was significantly decreased at 28 and 44 days in broilers fed enzyme supplemented diets. Conclusion: Results of this study indicated that supplementation diets with $500 \mathrm{mg} \mathrm{kg}^{-1}$ multi-enzyme (Endofeed W) in corn-soybean meal-wheat based diet improved broiler chickens feed to gain ratio, carcass yield and it can change the concentrations of thyroid hormones and some metabolites in blood, but it had not significant effect on carcass composition.
\end{abstract}

Key words: Multi-enzyme, performance, carcass characteristics, blood parameters, broilers

\section{INTRODUCTION}

Due to the chemical structure of plant cell wall matrix, NSP degrading enzymes has been recommended to enhance poultries performance. Enzyme supplementation is well documented as effective in breaking polymeric chains of NSPs and hence improving the nutritive value of feedstuffs (Giraldo et al., 2008). Therefore adding NSP-degrading enzymes in poultry diets has increased considerably in recent years. Birds do not produce enzymes like cellulase, xylanase, required for the digestion of NSPs. Supplementation of NSPs degrading enzymes may not only reduce the anti nutritive effects of NSPs, but also releases some nutrients from these, which could be utilized by the birds (Balamurugan and Chandrasekaran, 2009). However, the effects of exogenous enzymes can be variable and it depends on a large number of factors such as the age of the bird and the quality and type of diet (Bedford, 2000; Acamovic, 2001). The use of exogenous enzymes to improve the digestibility of corn-soybean meal diets for broilers is less well documented. Neither corn nor soybean meal is regarded as viscous feedstuffs even though they do contain appreciable amounts of NSP's. Corn contains approximately $0.9 \%$ soluble NSP and $6 \%$ insoluble NSP, whereas SBM contains approximately $6 \%$ soluble NSP and 18-21\% insoluble NSP (Knudsen, 1997). Noy 
and Sklan (1994) reported that ileal digestibility of corn starch rarely exceeds $85 \%$ in broilers between 4 and 21 days of age, indicating opportunities to further improve the digestibility of resistant starch in the jejunum and ileum through amylase supplementation. Furthermore, proteases could potentially degrade such soybean proteins as glycinin and $\beta$-conglycinin and some antinutritional factors (lectin and trypsin-inhibitor) in inadequately processed soybean meal (Thrope and Beal, 2001). Legume NSP are much more complex in structure than those present in cereals and, therefore, the use of "classical" NSP-degrading enzyme products tends to provide limited and inconsistent responses (Broz and Ward, 2007). Wheat is an important source of energy in broiler diets because of its high Starch (ST) and $\mathrm{CP}$ content and is often the only cereal in grower and finisher diets (Gutierrez del Alamo et al., 2008). In a survey of 18 wheat cultivars, Kim et al. (2003) reported that ST content ranged between 58.5 and $73.7 \%$, CP between 9.7 and $19.1 \%$ and Nonstarch Polysaccharide (NSP) between 7.8 and 11\% (on DM basis). The physical entrapment of wheat starch and protein by cell wall polysaccharides has been suggested as another important factor by which NSP exert their anti-nutritive properties (Bedford and Autio, 1996; Wiseman et al., 2000). When added to relevant poultry diets, NSP-degrading enzymes usually result in numerous beneficial effects, such as increased utilization of nutrients (e.g., fat and protein), improved AME values, increased growth rate, improved feed: Gain, decreased viscosity of intestinal digesta, reduced incidence of sticky excreta, improved litter conditions and reduced environmental pollution due to a decreased output of manure and gases such as ammonia (Broz and Ward, 2007; Costa et al., 2008). Enzyme supplementation can change the nutritional status and improve growth performance of broiler chickens fed a wheat diet, but which are also closely related to the regulation of metabolism and functioning of the growthrelated endocrine system. Nutritional status is an important factor in the regulation of plasma hormones and intermediary metabolism in broiler chickens (Gao et al., 2007; Buyse et al., 2002; Swennen et al., 2005).

Therefore, the objectives of this study were to examine the effects of enzyme supplementation on performance, carcass characteristics, carcass composition and some blood parameters in broiler chicken fed on corn-soybean meal-wheat diets.

\section{MATERIALS AND METHODS}

A total of 150, one-day old mixed-sex broiler chicks (Cobb 500) were obtained from a commercial hatchery on the hatching day. The experimental design was CRD with 2 treatments and 3 replicates with 25 chicks in each replicate. Treatments contain 2 levels of a multi-enzyme $\left(0.00\right.$ and $500 \mathrm{mg} \mathrm{kg}^{-1} \mathrm{DM}$, EndofeedW from GNC Bioferm Inc., Canada). The room was lit continuously during the whole experimental period and room temperature was controlled at $32^{\circ} \mathrm{C}$ from 1-3 days and then gradually reduced by $2-3^{\circ} \mathrm{C}$ per week to a final temperature of $20^{\circ} \mathrm{C}$. All diets were formulated to meet the nutrient requirements according to Cobb 500 rearing guideline. The composition and nutrient levels of the basal diet are shown in Table 1. Feed and water were provided ad libitum during the whole trial. The enzyme was obtained from Aspergillus niger and was prepared in Canada. It contained at least $2250 \mathrm{U} \mathrm{g}^{-1}$ arabinoxylanase and $700 \mathrm{U} \mathrm{g}^{-1}$ beta-glucanase activity. According to the manufacture, this enzyme product also contained activities of other enzymes, including cellulase, hemicellulase, protease, $\alpha$-amilase and $\alpha$-galactosidase. The experimental period lasted 44 days. Chicks were weighed at 1, 10, 28 and 44 days of age. Mortality was measured throughout the experiment. At 10 days of age, blood sample was collected from heart of 18 chicks and at 28 and 44 days of age blood sample was collected from a wing vein. Blood samples were keep on ice, centrifuged and plasma stored at $-20^{\circ} \mathrm{C}$ until hormone and metabolite analyses were carried out. The concentrations of plasma Thyroxine $\left(\mathrm{T}_{4}\right)$ and Triiodothyronine $\left(\mathrm{T}_{3}\right)$ were Measured by Radioimmunoassay (RIA) using standard commercial kits (Pishtazteb). The concentrations of glucose, cholesterol, triglyceride and uric acid were measured using appropriate commercial laboratory kits (zistshimi and parsazmoon). All plasma parameters were measured according to the manufacturer's instructions. At the end of the experiment (44 days) 2 birds from each pen with body weight close to the pen average body weight were selected for carcass analyses. After feed withheld for $9 \mathrm{~h}$, the selected birds were transported to the university pilot for processing. The chickens were slaughtered by cervical dislocation to determine the carcass characteristics.

Statistical analysis: Data of this experiment were analyzed by analysis of variance using GLM procedures (SAS Institute, 2001). Differences among means were compared by Duncan's multiple range test at 5\% probability (Duncan, 1955). Statistical model of this experiment was as follow:

$$
\mathrm{X}_{\mathrm{ij}}=\mu+\mathrm{T}_{\mathrm{i}}+\mathrm{e}_{\mathrm{ij}}
$$

where, $\mu, T_{i}$ and $e_{i j}$ are overall mean, the treatment and experimental error effects respectively. 
American J. Animal \& Vet. Sci., 5 (3): 221-227, 2010

Table 1: Composition of experimental diets in different periods of the experiment

\begin{tabular}{|c|c|c|c|}
\hline Ingredients (\%) & $\begin{array}{l}\text { Starter } \\
1-10 \text { days }\end{array}$ & $\begin{array}{l}\text { Grower } \\
11-28 \text { days }\end{array}$ & $\begin{array}{l}\text { Finisher } \\
29-44 \text { days }\end{array}$ \\
\hline Corn & 43.69 & 37.42 & 39.63 \\
\hline Soybean meal & 35.67 & 31.46 & 33.61 \\
\hline Wheat & 15.00 & 25.00 & 21.04 \\
\hline Vegetable oil & 1.83 & 2.35 & 1.63 \\
\hline Dicalcium phosphate & 1.30 & 1.19 & 1.16 \\
\hline Oyster shell & 1.23 & 1.31 & 1.40 \\
\hline Common salt & 0.30 & 0.30 & 0.30 \\
\hline Mineral premix $^{1}$ & 0.25 & 0.25 & 0.25 \\
\hline Vitamin premix ${ }^{2}$ & 0.25 & 0.25 & 0.25 \\
\hline DL-methionine & 0.32 & 0.30 & 0.34 \\
\hline L-Lysine $\mathrm{HCl}$ & 0.17 & 0.18 & 0.34 \\
\hline Total & 100.00 & 100.00 & 100.00 \\
\hline \multicolumn{4}{|l|}{ Calculated analysis } \\
\hline $\operatorname{ME}\left(\mathrm{kcal} \mathrm{kg}^{-1}\right)$ & 2950.00 & 3000.00 & 3050.00 \\
\hline Crude protein (\%) & 22.00 & 21.00 & 18.00 \\
\hline Calcium (\%) & 0.86 & 0.86 & 0.86 \\
\hline Available phosphorus (\%) & 0.43 & 0.43 & 0.43 \\
\hline Sodium $(\%)$ & 0.14 & 0.14 & 0.14 \\
\hline Arginine (\%) & 1.47 & 1.36 & 1.09 \\
\hline Lysine $(\%)$ & 1.33 & 1.23 & 1.08 \\
\hline Methionine (\%) & 0.35 & 0.33 & 0.28 \\
\hline Methionine + cysteine $(\%)$ & 1.00 & 0.94 & 0.88 \\
\hline Threonine (\%) & 0.86 & 0.80 & 0.64 \\
\hline Tryptophan (\%) & 0.28 & 0.26 & 0.21 \\
\hline
\end{tabular}

${ }^{1}$ : Supplied per kilogram of diet: $6050 \mu \mathrm{g}$ vitamin A (retinyl acetate + retinyl palmitate), $55 \mu \mathrm{g}$ vitamin $\mathrm{D} 3,22.05 \mu \mathrm{g}$ vitamin $\mathrm{E}$ (alphatopheryl acetate), $2.0 \mathrm{mg}$ vitamin $\mathrm{K} 3,5 \mathrm{mg}$ vitamin $\mathrm{B} 1,6.0 \mathrm{mg}$ vitamin B2, $60 \mathrm{mg}$ vitamin B3, $4 \mathrm{mg}$ vitamin B6, $0.02 \mathrm{mg}$ vitamin $\mathrm{B} 12,10.0 \mathrm{mg}$ pantothenic acid, $6.0 \mathrm{mg}$ folic acid, $0.15 \mathrm{mg}$ biotin, $0.625 \mathrm{mg}$ ethoxyquin; ${ }^{2}$ : Supplied per kg of diet: $500 \mathrm{mg} \mathrm{CaCO}_{3}, 80$ $\mathrm{mg} \mathrm{Fe}, 80 \mathrm{mg} \mathrm{Zn}, 80 \mathrm{mg} \mathrm{Mn}, 10 \mathrm{mg} \mathrm{Cu}, 0.8 \mathrm{mg} \mathrm{I}, 0.3 \mathrm{mg} \mathrm{Se}$

\section{RESULTS}

Performance: The effects of Endofeed W enzyme supplementation on broiler performance for 10,28 and 44 days are shown in Table 2 and 3. Relative growth, energy efficiency and protein efficiency was significantly improved $(\mathrm{p}>0.05)$ by enzyme supplementation from 11-28 days. Enzyme inclusion increased energy and protein efficiency and decreased feed intake, body weight gain and feed to gain ratio from 29-44 days of age $(p<0.05)$. Relative growth, energy efficiency and protein efficiency was increased and feed intake and feed to gain ratio was decreased by enzyme supplementation from 1-44 days $(\mathrm{p}<0.05)$.

Carcass characteristics and composition: Effects of enzyme supplementation on carcass characteristics on 44 days age are shown in Table 4. Enzyme supplementation increased carcass percentage and thighs + drumsticks percentage significantly $(\mathrm{p}<0.05)$.
Table 2: Effects of enzyme supplementation on body weight gain feed intake and feed/gain in broiler chickens

\begin{tabular}{|c|c|c|c|c|}
\hline Items & $\begin{array}{l}\mathrm{T}_{1} \\
\text { (no enzyme) }\end{array}$ & $\begin{array}{l}\mathrm{T}_{2}(0.05 \% \\
\text { enzyme) }\end{array}$ & SEM & Significance \\
\hline \multicolumn{5}{|l|}{$1-10$ days } \\
\hline Weight gain (g/bird) & 198.20 & 192.30 & 2.31 & NS \\
\hline Feed intake (g/bird) & 244.40 & 235.00 & 3.11 & NS \\
\hline Feed/gain $\left(\mathrm{g} \mathrm{g}^{-1}\right)$ & 1.23 & 1.21 & 0.01 & NS \\
\hline \multicolumn{5}{|l|}{ 11-28 days } \\
\hline Weight gain (g/bird) & 1087.20 & 1107.70 & 10.40 & NS \\
\hline Feed intake (g/bird) & 1900.00 & 1911.60 & 12.92 & NS \\
\hline Feed/gain $\left(\mathrm{g} \mathrm{g}^{-1}\right)$ & 1.75 & 1.74 & 0.01 & NS \\
\hline \multicolumn{5}{|l|}{ 29-44 days } \\
\hline Weight gain (g/bird) & 1643.90 & 1603.20 & 13.42 & * \\
\hline Feed intake (g/bird) & 3320.50 & 3153.30 & 14.97 & * \\
\hline Feed/gain $\left(\mathrm{g} \mathrm{g}^{-1}\right)$ & 2.02 & 1.97 & 0.01 & * \\
\hline \multicolumn{5}{|l|}{$1-44$ days } \\
\hline Weight gain (g/bird) & 2929.40 & 2903.30 & 11.60 & * \\
\hline Feed intake ( $\mathrm{g} /$ bird $)$ & 5465.00 & 5300.00 & 13.10 & * \\
\hline Feed/gain $\left(\mathrm{g} \mathrm{g}^{-1}\right)$ & 1.86 & 1.82 & 0.01 & * \\
\hline
\end{tabular}

NS: Not Significant; *: $\mathrm{p}<0.05$

Table 3: Effects of enzyme supplementation on relative growth, energy and protein efficiency in broiler chicks

\begin{tabular}{lcccl}
\hline & \multicolumn{3}{l}{$\mathrm{T}_{2}$} \\
Items & $\begin{array}{l}\mathrm{T}_{1} \\
\text { (no enzyme) }\end{array}$ & $\begin{array}{l}(0.05 \% \\
\text { enzyme) }\end{array}$ & SEM & Significance \\
\hline 1-10 days & & & & \\
Relative growth & 4.950 & 4.800 & 0.050 & $\mathrm{NS}$ \\
$\begin{array}{l}\text { Energy efficiency } \\
\text { Protein efficiency }\end{array}$ & 0.274 & 0.276 & 0.003 & $\mathrm{NS}$ \\
11-28 days & 3.680 & 3.710 & 0.050 & $\mathrm{NS}$ \\
Relative growth & 4.990 & 5.340 & 0.040 & $*$ \\
Energy efficiency & 0.214 & 0.222 & 0.001 & $*$ \\
$\begin{array}{l}\text { Protein efficiency } \\
\text { 29-44 days }\end{array}$ & 3.060 & 3.180 & 0.010 & $*$ \\
Relative growth & 1.020 & 1.030 & 0.013 & $\mathrm{NS}$ \\
Energy efficiency & 0.158 & 0.169 & 0.001 & $*$ \\
Protein efficiency & 2.680 & 2.870 & 0.020 & $*$ \\
1-44 days & & & & \\
Relative growth & 71.240 & 74.000 & 0.180 & $*$ \\
Energy efficiency & 0.183 & 0.193 & 0.001 & $*$ \\
Protein efficiency & 2.890 & 3.040 & 0.010 & $*$ \\
\hline
\end{tabular}

NS: Not Significant; *: $\mathrm{p}<0.05$

Table 4: Effects of enzyme supplementation on carcass characteristics of broiler chickens at 44 days of age

\begin{tabular}{|c|c|c|c|c|}
\hline Items & $\begin{array}{l}T_{1} \text { (no } \\
\text { enzyme) }\end{array}$ & $\begin{array}{l}\mathrm{T}_{2}(0.05 \% \\
\text { enzyme) }\end{array}$ & SEM & Significance \\
\hline Carcass $\left(\% \mathrm{LW}^{\mathrm{1}}\right)$ & 78.100 & 80.110 & 0.330 & $*$ \\
\hline Breast $\left(\% \mathrm{CW}^{2}\right)$ & 32.500 & 33.130 & 0.270 & NS \\
\hline $\begin{array}{l}\text { Thighs + Drumsticks } \\
(\% \mathrm{CW})\end{array}$ & 24.350 & 25.460 & 0.320 & * \\
\hline Wings (\% CW) & 7.340 & 7.360 & 0.150 & NS \\
\hline Heart $(\% \mathrm{CW})$ & 0.590 & 0.610 & 0.006 & NS \\
\hline Liver (\% CW) & 2.350 & 2.360 & 0.010 & NS \\
\hline $\begin{array}{l}\text { Proventriculus } \\
(\% \mathrm{CW})\end{array}$ & 0.341 & 0.338 & 0.005 & NS \\
\hline Gizzard (\% CW) & 1.300 & 1.290 & 0.010 & NS \\
\hline Splin $(\% \mathrm{CW})$ & 0.096 & 0.095 & 0.004 & NS \\
\hline Abdominal fat content & 2.980 & 3.020 & 0.030 & NS \\
\hline $\begin{array}{l}\text { Feet }(\% \mathrm{LW}) \\
(\% \mathrm{CW})\end{array}$ & 3.460 & 3.470 & 0.060 & NS \\
\hline $\begin{array}{l}\text { Carcass dry matter } \\
(\% \mathrm{DM})\end{array}$ & 28.800 & 28.160 & 0.520 & NS \\
\hline Carcass fat $(\% \mathrm{DM})$ & 40.690 & 40.810 & 0.580 & NS \\
\hline Carcass protein (\% DM) & 50.110 & 50.030 & 0.570 & NS \\
\hline Carcass ash (\% DM) & 9.120 & 9.090 & 0.050 & NS \\
\hline
\end{tabular}

${ }^{1}$ : Live weight; ${ }^{2}$ : Carcass weight; NS: Not Significant; $*$ : $p<0.05$ 
Enzyme addition had no significant effect on Breast percentage, wings percentage, Heart percentage, liver percentage, proventriculus percentage, gizzard percentage, splin percentage, abdominal fat pad percentage and feet percentage. In general, enzyme supplementation decreased the relative size of the digestive organs and increased carcass yield. The results showed that enzyme supplementation did not have significant effect on broilers carcass composition Table 4.

Blood parameters: The effects of multi-enzyme supplementation on some blood parameters for 10, 28 and 44 days are shown in Table 5. The results of this study showed that enzyme addition increased the concentration of blood $\mathrm{T}_{3}(\mathrm{p}<0.05)$ at 28 and 44 days and reduced the concentration of blood $\mathrm{T}_{4}(\mathrm{p}<0.05)$ at 44 days of age.

In this study the concentration of blood glucose was significantly elevated by enzyme supplementation at 44 days of age.

Present study showed that adding Endofeed-W multi-enzyme to broilers diet significantly increased the concentration of blood total cholesterol at 10, 28 and 44 days $(\mathrm{p}<0.05)$.

Enzyme supplementation was reduced the concentration of blood uric acid at 28 and 44 days $(p<0.05)$. This suggests that the enzyme preparation increased nutrient metabolism, particularly protein anabolism of birds, therefore, promoting the growth of chickens.

Table 5: Effects of enzyme supplementation on plasma $T_{3}, T_{4}$, glucose, cholesterol, HDL, LDL, triglyceride and uric acid

\begin{tabular}{|c|c|c|c|c|}
\hline Items & $\begin{array}{l}\mathrm{T}_{1} \\
\text { (no enzyme) }\end{array}$ & $\begin{array}{l}\mathrm{T}_{2} \\
(0.05 \% \text { enzyme })\end{array}$ & SEM & Significance \\
\hline \multicolumn{5}{|l|}{10 days } \\
\hline $\mathrm{T}_{3}\left(\mu \mathrm{g} \mathrm{dL} \mathrm{L}^{-1}\right)$ & 1.7 & 2.0 & 0.08 & NS \\
\hline $\mathrm{T}_{4}\left(\mathrm{nmol} \mathrm{L}^{-1}\right)$ & 30.7 & 30.4 & 1.20 & NS \\
\hline Glucose $\left(\mathrm{mg} \mathrm{dL}^{-1}\right)$ & 240.1 & 255.9 & 5.25 & NS \\
\hline Cholesterol $\left(\mathrm{mg} \mathrm{dL}^{-1}\right)$ & 137.9 & 139.5 & 0.37 & $*$ \\
\hline Triglyceride $\left(\mathrm{mg} \mathrm{dL}^{-1}\right)$ & 33.4 & 36.1 & 0.40 & $*$ \\
\hline $\operatorname{Uric} \operatorname{acid}\left(\mathrm{mg} \mathrm{L}^{-1}\right)$ & 148.3 & 148.1 & 0.41 & NS \\
\hline \multicolumn{5}{|l|}{28 days } \\
\hline $\mathrm{T}_{3}\left(\mu \mathrm{g} \mathrm{dL}^{-1}\right)$ & 3.2 & 3.6 & 0.09 & $*$ \\
\hline $\mathrm{T}_{4}\left(\mathrm{nmol} \mathrm{L}^{-1}\right)$ & 16.7 & 14.9 & 0.68 & NS \\
\hline Glucose $\left(\mathrm{mg} \mathrm{dL}^{-1}\right)$ & 235.9 & 237.7 & 0.66 & NS \\
\hline Cholesterol (mg dL $\left.{ }^{-1}\right)$ & 137.0 & 140.3 & 0.69 & $*$ \\
\hline Triglyceride $\left(\mathrm{mg} \mathrm{dL}^{-1}\right)$ & 34.1 & 34.9 & 0.37 & NS \\
\hline $\begin{array}{l}\text { Uric acid }\left(\mathrm{mg} \mathrm{L}^{-1}\right) \\
44 \text { days }\end{array}$ & 147.3 & 137.1 & 1.07 & $*$ \\
\hline $\mathrm{T}_{3}\left(\mu \mathrm{g} \mathrm{dL}^{-1}\right)$ & 0.8 & 2.0 & 0.11 & $*$ \\
\hline $\mathrm{T}_{4}\left(\mathrm{nmol} \mathrm{L}^{-1}\right)$ & 32.8 & 26.9 & 1.34 & $*$ \\
\hline Glucose $\left(\mathrm{mg} \mathrm{dL}^{-1}\right)$ & 232.9 & 235.3 & 0.57 & $*$ \\
\hline Cholesterol (mg dL $\left.{ }^{-1}\right)$ & 140.0 & 146.4 & 1.00 & $*$ \\
\hline Triglyceride $\left(\mathrm{mg} \mathrm{dL}^{-1}\right)$ & 37.2 & 42.2 & 0.70 & $*$ \\
\hline Uric acid $\left(\mathrm{mg} \mathrm{L}^{-1}\right)$ & 168.1 & 145.8 & 1.12 & $*$ \\
\hline
\end{tabular}

NS: Not Significant; *: $\mathrm{p}<0.05$

\section{DISSCUSION}

Performance: The need for exogenous enzyme supplements in corn-soybean meal diets is generally ignored. However, some studies reported a significantly positive growth performance response in corn-based diets supplemented with enzymes, either multiple enzymes which contains xylanase, protease and amylase or a single protease enzyme (Zanella et al., 1999; Ghazi et al., 2002; Yu et al., 2007). Responses to enzyme supplementation depend on the bird's age, which is apparently related to both the type of gut microflora present and the physiology of the bird. Old birds, because of the enhanced fermentation capacity of the microflora in their intestines, have a greater capacity to deal with the effects of high viscosity (Choct et al., 1996; Vranjes and Wenk, 1995). Enzyme supplementation might improve broiler performance by improving nutrient digestibility. This mechanism might be induced, at least partially, by a reduction of the viscosity Lazaro et al. (2003). The results of this study are in agreements with previous results (Gutierrez del Alamo et al., 2008; Gao et al, 2007; Yu et al., 2007).

Carcass characteristics and composition: Results of the present study are in agreements with findings of Wang et al. (2005) and Alam et al. (2003). They reported increased carcass yield by addition of enzymes in diet attributable to higher fat deposition in carcass and also for increased breast meat yield. On the other hand, this result contradict with some researchers that reported carcass yield had no significant difference, among enzyme treated and non-treated diets.

Blood parameters: Similar to mammals, the hormonal control of growth in birds is complex and involves a variety of hormones, including thyroid hormones, Growth Hormone (GH), somatomedins and other circulating growth factors, androgens, insulin, prolaction and glucocorticoids (Scanes and Lauterio, 1984). A close relationship between the somatotropic and thyrotropic axis in regulation of growth and development of broiler chickens has been found and they play an important role in poultry growth. Some studies suggest that nutrition is an important factor in the regulation of plasma hormones and of their receptors gene expression in many tissues of chickens. For example, protein deficiency changes the ratio of circulating concentrations of $\mathrm{T}_{3}$ and $\mathrm{T}_{4}$, reduces circulating concentrations of IGF-I and increases GH concentration (Scanes and Griminger, 1990). Another possibility is that there are physiologically active peptides and oligosaccharides or some other growth- 
promoting substances in digesta of gut produced by exoenzymes and endoenzymes. These active substances might have affected the cell receptors, therefore, producing physiological effects (Han, 1997).

In this study enzyme supplementation influenced thyriod hormones concentrations. This suggests that enzyme addition directly or indirectly promoted an enhanced activity of deiodinase in liver and kidney tissues, promoting the transformation of $\mathrm{T}_{4}$ into $\mathrm{T}_{3}$ (Collin et al., 2003). Nutritional factors (diet quantity and composition) also affect intermediary metabolism, resulting in the changes of plasma metabolite levels in poultry (Buyse et al., 2002; Swennen et al., 2005).

Exogenous enzymes used in the diets of young chicks would be very beneficial in improving nutrient digestibility in at least 2 ways: (1) by supplying enzymes that the chick cannot produce in sufficient quantity by itself, or (2) even though the chick can produce enough quantity of an enzyme by itself, exogenous enzyme may reduce the requirement for the enzyme, thus making more nutrients and energy available for growth of the chick at that critical stage (Olukosi et al., 2007) and this can be a reason for increased blood glucose concentration at 44 days of age.

Studies with animal models have shown that high levels of dietary cholesterol, saturated fatty acids and an increased small intestinal uptake of these components due to, for example, a low dietary fiber concentration or enzyme supplementation of the diet may increase plasma cholesterol levels (Mancini and Parillo, 1991; Sutton et al., 1985). LDL and HDL-cholesterol is formed when cholesterol and fats get together in circulatory system. With changing the physicochemical properties of intestinal chyme due to the presence of soluble NSPs in wheat and the known interaction effects of them with saturated fatty acids (Kussaibati et al., 1982) and the effect of NSPdegrading enzymes might explain some of these results. Adding enzyme may alleviate the limitations present for the function of bile salts and the emulsifying properties of them in intestinal chyme and therefore it might be a reason for increasing total fat in blood. It is reported that the digestion of big molecules of carbohydrates with pentosanase (arabinoxylanase) can change the viscouse nature of intestinal chyme and therefore improves fat digestibility (Bedford et al., 1991).

In birds, purine bases are degraded to uric acid. In addition, purines are formed from excess amino-N, which are subsequently degraded to uric acid and excreted in urine (Buyse et al., 2002). Correlation analysis showed a significant negative relationship between plasma uric acid levels and efficiency of protein retention (Swennen et al., 2005).

\section{CONCLUSION}

In conclusion, supplementation diets with $500 \mathrm{mg}$ $\mathrm{kg}^{-1}$ multi-enzyme (Endofeed W) in broiler chickens (Cobb 500) diets improved feed to gain ratio, carcass yield and it can change the concentrations of thyroid hormones and some metabolites in blood, but it had not significant effect on carcass composition.

\section{ACKNOWLEDGMENT}

The researcher thanks Dr. Asadollah Teimouri Yansari and Dr. Zarbakht Ansari Pirsaraei for their kind assisting in conducting the experiment and data analysis.

\section{REFERENCES}

Acamovic, T., 2001. Commercial application of enzyme technology for poultry production. World Poult. Sci. J., 57: 225-243. DOI: 10.1079/WPS20010016

Alam, M.J., M.A.R. Howlider, M.A.H. Pramanik and M.A. Haque, 2003. Effect of exogenous enzyme in diet on broiler performance. Int. J. Poult. Sci., 2: 168-173. DOI: 10.3923/ijps.2003.168.173

Balamurugan, R. and D. Chandrasekaran, 2009. Effect of multienzyme supplementation on weight gain, feed intake, feed efficiency and blood glucose in broiler chickens. Indian J. Sci. Technol., 3: 193-195.

Bedford, M.R. and K. Autio, 1996. Microscopic examination of feed and digesta from wheat-fed broiler chickens and its relation to bird performance. Poult. Sci., 75: 1-14. DOI: 10.1590/S1516-35982007000400011

Bedford, M.R., 2000. Exogenous enzymes in monogastric nutrition-their current value and future benefits. Anim. Feed Sci. Technol., 86: 1-13. DOI: 10.1016/S0377-8401(00)00155-3

Bedford, M.R., H.L. Classen and G.L. Campbell, 1991. The effects of pelleting, salt and pentosanase on the viscosity of intestinal contents and the performance of broiler broilers fed rye. Poult. Sci., 70: 1571-1577. PMID: 1886869

Broz, J. and N.E. Ward, 2007. The role of vitamins and feed enzymes in combating metabolic challenges and disorders. J. Applied Poult. Res., 16: 150-159. DOI: $10.1590 /$ S1516-35982008001300027 
Buyse, J., K. Jassens, S. van der Geyten, P. van As, E. Decuypere and V.M. Darras, 2002. Pre-and postprandial changes in plasma hormone and metabolite levels and hepatic deiodinase activities in meal-fed broiler chickens. Br. J. Nutr., 88: 641-653. DOI: $10.1079 / \mathrm{BJN} 2002741$

Choct, M., R.J. Hughes, J. Wang, M.R Bedford, A.J. Morgan and G. Annison, 1996. Increased small intestinal fermentation is partly responsible for the anti-nutritive activity of non-starch polysaccharides in chickens. Br. Poult. Sci., 37: 609-621. DOI: 10.1080/00071669608417891

Collin, A., R.D. Malheiros, V.M.B. Moraes, P.V.A. Veerle and M. Darras et al., 2003. Effects of dietary macronutrient content on energy metabolism and uncoupling protein mRNA expression in broiler chickens. Br. J. Nutr., 90: 261-269. PMID: 12908886

Costa, F.G.P., C.C. Goulart, D.F. Figueiredo, C.F.S. Oliveira and J.H.V. Silva, 2008. Economic and environmental impact of using exogenous enzymes on poultry feeding. Int. J. Poult. Sci., 7: 311-314.

Duncan, D.B., 1955. Multiple ranges and Multiple Ftest. Biometrics, 11: 1-42.

Gao, F., Y. Jiang, G.H. Zhou and Z.K. Han, 2007. The effects of xylanase supplementation on performance, characteristics of the gastrointestinal tract, blood parameters and gut microfelora in broilers fed on wheat-based diets. Anim. Feed Sci. Technol., 142: 173-184. DOI: 10.1016/j.anifeedsci.2007.07.008

Ghazi, S., J.A. Rooke, H. Galbraith and M.R. Bedford, 2002. The potential for the improvement of the nutritive value of soya-bean meal by different proteases in broiler chicks and broiler cockerels. Br. Poult. Sci., 43: 70-77. DOI: 10.1080/00071660120109935

Giraldo, L.A., M.L. Tejido, M.J. Ranilla, S. Ramos and M.D. Carro, 2008. Influence of direct-fed fibrolytic enzymes on diet digestibility and ruminal activity in sheep fed grass hay-based diet. J. Anim. Sci., 86: 1617-1623. DOI: $10.2527 /$ jas.2007-0343

Gutierrez del Alamo, A., M.W.A. Verstegen, L.A. Den Hartog, P. Perez de Ayala and M.J. Villamide, 2008. Effect of wheat cultivar and enzyme addition to broiler chicken diets on nutrient digestibility, performance and apparent metabolizable energy content. Poult. Sci., 87: 759-767. PMID: 18339998

Han, Z. K., 1997. Effect of Enzyme Supplementation of Diets on the Physiological Function and Performance of Poultry. In: Enzymes in Poultry and Swine Nutrition, Marquardt, R.R. and Z.K. Han (Eds.). IDRC, Ottawa, Canada, ISBN: 1-55250278-3, pp: 29-44.
Kim, J.C., B.P. Mullan, P.H. Simmins and J.R. Pluske, 2003. Variation in the chemical composition of wheat's grown in Western Australia as influenced by variety, growing region, season and post-harvest storage. Aust. J. Agric. Res., 54: 541-550. DOI: 10.1071/AR02183

Knudsen, K.E.B., 1997. Carbohydrate and lignin contents of plant materials used in animal feeding. Anim. Feed Sci. Technol., 67: 319-338. DOI: 10.1016/S0377-8401(97)00009-6

Kussaibati, R., L. Guillaume and B. Leclerq, 1982. The effects of age, dietary fat and bile salts and feeding rate on apparent and true metabolizable energy values in chickens. Br. Poult. Sci., 23: 292-303. PMID: 7139389

Lazaro, R., M. Garcia, P. Medel and G.G. Mateos, 2003. Influence of enzymes on performance and digestive parameters of broilers fed rye-based diets. Poult. Sci., 82: 132-140. PMID: 12580255

Mancini, M. and M. Parillo, 1991 Lipid intake and therosclerosis. Ann. Nutr. Metab., 35: 103-108. DOI: $10.1159 / 000177689$

Noy, Y. and D. Sklan, 1994. Digestion and absorption in the young chick. Poult. Sci., 73: 366-373. PMID: 7724461

Olukosi, O.A., A.J. Cowieson and O. Adeola, 2007. Age-related influence of a cocktail of xylanase, amylase and protease or phytase individually or in combination in broilers. Poult. Sci., 86: 77-86. PMID: 17179419

SAS Institute, 2001. SAS User's Guide Statics. Version 82 Edn. SAS Institute Inc., Cary, NC., USA.,

Scanes, C.G. and P. Griminger, 1990. Endocrinenutrition interactions in birds. J. Exp. Zool., 4: 98-105. PMID: 1974808

Scanes, C.G. and T. J. Lauterio, 1984. Growth hormone: Its physiology and control. J. Exp. Zool., 232: 443-452. PMID: 6151579

Sutton, C.D., W.M. Muir and G.E.J. Mitchell, 1985. The effect of dietary cholesterol, energy intake and oxygen consumption on cholesterol metabolism in the chick. Poult. Sci., 64: 502-509. PMID: 3991424

Swennen, Q., G.P.J. Janssens, S. Millet., G. Vansant, E. Decuypere and J. Buyse, 2005. Effect of substitution between fat and protein on feed intake and its regulatory mechanisms in broiler chickens: endocrine functioning and intermediary metabolism. Poult. Sci., 84: 1051-1057. PMID: 16050122

Thrope, J. and J.D. Beal, 2001. Vegetable Proteins Meals and the Effects of Enzymes. In: Enzymes in Farm Animal Nutrition, Bedford, M.R. and G.G. Partridge (Eds.). CABI Publishers, Wallingford, Oxon, UK., ISBN: 10: 0851993931, pp: 125-143. 
Vranjes, M. V. and C. Wenk, 1995. Impudence of dietary enzyme complex on the performance of broilers fed on diets with and without antibiotic supplementation. Br. Poult. Sci., 36: 265-275. PMID: 7655900

Wang, Z.R., S.Y. Qiao, W.Q. Lu and D.F. Li, 2005. Effects of enzyme supplementation on performance, nutrient digestibility, gastrointestinal morphology and volatile fatty acid profiles in the hindgut of broilers fed wheat-based diets. Poult. Sci., 84: 875-881. PMID: 15971523

Wiseman, J., N.T. Nicol and G. Norton, 2000. Relationship between Apparent Metabolisable (AME) values and in vivo/in vitro starch digestibility of wheat for broilers. W. Poult. Sci. J., 56: 306-318. DOI: 10.1079/WPS20000022
Yu, B., S.T. Wu, C.C. Liu, R. Gauthier and P.W.S. Chiou, 2007. Effects of enzyme inclusion in a corn-soybean diet on broiler performance. Anim. Feed. Sci. Tech., 134: 283-294. DOI: 10.1016/j.anifeedsci.2006.09.017

Zanella, I., N.K. Sakomura, F.G. Silversides, A. Fiqueirdo and M. Pack, 1999. Effect of enzyme supplementation of broiler diets based on corn and soybeans. Poult. Sci., 78: 561-568. PMID: 10230910 